\title{
The End of Euro-American Civilization? Reflections on the Current State of Transatlantic Relations
}

\section{Egdunas Racius *}

It is ironic that the alliance between Europe and the United States has been put into question by disagreements over the Iraq crisis in late 2002 and early 2003 . The simmering talk of the transatlantic rift — and, to be fair, there has been talk of such a rift for quite some time starting as early as beginning of the 1990s, especially among political observers and analyst-erupted and was elevated to the highest echelons of policy makers. The long-denied rift confirmed itself on the lips of those who make ultimate political decisions: the Americans blamed Europeans (at least some of them) as betrayers of their commitments to the alliance, while Europeans accused the Americans of hot-headedness. There was a bitter exchange of degrading phrases between the two sides just prior to the outbreak of the war in Iraq, pitting particularly the French and Germans versus the Americans.

Some might - or might like to - see the Iraq crisis as a decisive watershed that shattered the long-nurtured hopes of an idyllic and permanent alliance between the U.S. and Europe. Though such a conclusion in itself would not necessarily be inaccurate, one needs to highlight the premises on which it could be based.

At the outset, it should be made clear what is meant by Europe. Secondly, one has to define the essence of the 'alliance' between Europe and the U.S. Thirdly, the role and mission of NATO has to be reevaluated. Only when these primary issues are addressed can one proceed to assess whether there is a rift, how deep it is, and what are its real causes.

We shall begin with Europe. There have been and still are discussions over the question, What constitutes Europe? The criteria offered to measure Europeanness range from geography to language to religious tradition (as a rule, identified with Christianity) to a more abstract concept of common values. And, if there is a unanimous agreement over what constitutes the core of Europe- the countries of so-called Western Europe - there is a virtually insoluble disagreement concerning the periphery. Russia and Turkey, for example, are sometimes included in the notion of Europe, while at other times they are excluded. The small states in the Caucasus are also in limbo, for they do not consider themselves as part of Asia (this applies at least to Georgia and Armenia), yet are not always welcome at pan-European forums. And what about Israel? The majority of its citizens are of European descent, its sportsmen play in European championships, yet geographically Israel is in the Near East.

As for geography, it is not much help regarding the eastern borders of the continent, for one is never sure where exactly Europe ends and Asia begins. Moreover, it divides at least one country, namely Russia, between two continents. Yet it is precisely a lib-

* Dr. Egdunas Racius is Assistant Professor at the Institute of International Relations and
Political Sciences, Vilnius University, Lithuania. 
eral approach to geography that has governed the political definition of Europe in the realm of the Council of Europe: Russia, Turkey, Azerbaijan, Georgia, and Armenia are among the forty-five member states of the Council. One may argue that, had Israel applied, it would have been admitted as a member state also.

Religion as a criterion is not of much use either. In the nineteenth century, the Balkans were sometimes considered part of the Near East, for parts of the region were either under Ottoman rule (at the time Turkey was not yet considered part of Europe), or a majority of the populations were Muslim. ${ }^{1}$ Samuel Huntington, in his infamous 1993 essay, divided Europe into two civilizational zones, one Western Christian (true European) and the other Eastern Christian (quasi-European), thus effectively making two distinct Europes. ${ }^{2}$ And although this division might serve his theory of a clash of civilizations, it hardly helps one to grasp current political processes, such as Euro-Atlantic integration, in countries of Eastern Europe such as Bulgaria, Romania, Macedonia, and even Ukraine.

The criterion of common values and life styles is inevitably - though, admittedly, not exclusively - tied to religious traditions and there always is a temptation to fall back to the religion criterion. What values can be considered on the one side uniquely European, and on the other side, common to most if not all Europeans? One may argue that at the present time these values include liberalism, democracy, respect for human rights, freedom of speech and conscience, and the rule of law. ${ }^{3}$ But how long have these values been genuinely shared in Europe? Barely over a decade. Therefore, there should be some other, deeper common values that hold Europe together. But just what exactly these values would be is neither clear nor self-evident. Involuntarily, one is drawn to think of cultural regions where it is much easier to find the commonalities that create a distinct Weltanschauung of a certain European cultural unit. Thus, one can speak much in the vein of Max Weber, who laid emphasis on the relation between Protestantism and the capitalist spirit, and separated the Protestant North from the Catholic South and East, not to mention the Orthodox East. Or alternatively, one can speak of Anglo-Saxon, Scandinavian, Latin, and Slav cultures, with their distinct world-views revealed in their differing life styles.

The issue of Europeanness is made even more complex on the micro level if one takes into account the presence of immigrants in Europe from outside the continent. Though there are no precise statistical data, one can safely assume that there are some 35-40 million immigrants and children of immigrants residing in Europe. In the countries of the EU, there are some 12-15 million Muslims alone, most of whom are immigrants or children of immigrants from North Africa, the Indian subcontinent, and the Middle East. This wave of immigration has been changing not only the ethno-religious

${ }^{1}$ For a discussion of borders of the Middle East, see H.D. Davison, "Where is the Middle East?" Foreign Affairs 39:4 (1960).

2 Samuel Huntington, "Clash of Civilizations?" Foreign Affairs 72:3 (1993): 25-26; see also map on 30 .

${ }^{3}$ One has to admit that these values are still somewhat superficial in Turkey and Russia. 
composition of European societies, but profoundly affects the social behavior of members of these societies and challenges value systems that are commonly referred to as 'European.' It has, however, to be admitted that the challenges that immigration poses in Europe are more of an issue for the future, albeit in the near term. For the time being, one can still speak of Europe as a conglomerate of indigenous cultures.

The perception of Europe, complex as it is, was made even more complicated by statements made by the U.S. Secretary of Defense Donald Rumsfeld who, on 22 January 2003, in response to a journalist's question on Europe's position in the Iraq crisis, divided Europe into "old Europe" and "new Europe." Though initially annoyed, those described as "old" (France and Germany) soon turned Rumsfeld's remarks into an assertion of their standing in Europe, assuming that "old" meant civilized, calm, collected, and wise. ${ }^{4}$ Those countries labeled as "new" took the title as a prize, a sort of recognition by their primary (sole?) ally and protector, the United States. There arose a possibility of a rift within Europe itself, which was aggravated by harsh talk by the French President Chirac chiding the "new" Europeans for their support for the U.S. invasion of Iraq at a EU Summit in February 2003, describing them as "poorly-raised children." The French, and to a lesser extent the Germans, reprimanded the "new" Europeans for their presumed misbehavior in supporting the U.S. in its push to invade Iraq. The French and Germans were irritated by the Eastern Europeans' insensitivity toward not so much the concept of a united European foreign policy as the perceived betrayal of Europeanness, as opposed to an embrace of Americanness.

To what extent does this talk of "old" and "new" Europe make sense? Was it just a rhetorical move by the Bush Administration to achieve some political objective? Or was it a confirmation of the administration's official position with respect to Europe? It is hard to tell what exactly prompted Rumsfeld to say what he said, and it is irrelevant to the discussion at hand. What is relevant is that Rumsfeld's remarks gave a hint that the differences within Europe are not so much economic, which is obvious, or political - this, after all, was evident in the event of the Iraq crisis, but was rather circumscribed by diverging world-views and cultural experiences. One has to admit that Rumsfeld's division of Europe roughly coincides with the divide between former European imperial powers (such "old” European countries as France, Germany, Belgium, and Russia were empires, or at least had aspirations to be) and former colonies or client states (practically all "new" European countries used to be part of some empire or another, be it Russia, Austria-Hungary, or Ottoman Turkey). It is true, however, that some of the former imperial powers (Spain, Great Britain) were not included among the "old" Europeans described by Rumsfeld, but their identification with the

4 French government spokesman Jean-Francois Cope's reaction to Rumsfeld's formulation included the following: "An 'old' continent - a continent somewhat ancient in its historical, cultural, political, economic traditions - can sometimes be infused with a certain wisdom, and wisdom can sometimes make for good advice." Cited in Mark Baker, "U.S.: Rumsfeld's 'Old' and 'New' Europe Touches on Uneasy Divide," available at http://www.rferl.org/nca/features/ 2003/01/24012003172118.asp. 
"new" Europe goes only as deep as their joint support for the U.S.-led invasion of Iraq. Moreover, the decision to go along with the United States in the case of some smaller EU member states, like Denmark, was motivated by very pragmatic short-term objectives; at a different time and under different circumstances, these states may well have made the opposite decision.

Appreciating the fact that the "new" European nations Rumsfeld had in mind (chiefly the Vilnius Ten, a.k.a. former Communist satellites, some of which are governed by Communists turned social democrats) are indeed new countries with a traumatic past - some had even never previously been independent countries, while some were states subjected to the Soviet yoke - and low levels of social or political integrity facilitates the recognition of the division of the continent into "old" and "new" Europe. Most of the members of the "new" Europe just a dozen years ago were not players in world politics, much less in European politics - as it was somewhat sarcastically put in The Economist, "for many east Europeans, history seems to have started in 1989."5 Now, the newly created or reborn states are desperately trying to make up for lost time, and aim at putting themselves on the same footing as the old players. Their drive for recognition as actors on the stage of international politics, on the one hand, is natural. On the other hand, these countries seem to be seeking this goal at almost all costs, something that irritates the "old" Europeans, who have assumed a patronizing role in transforming "new" Europeans into good old Europeans - in their image, naturally. Disagreements inside the EU and the overzealousness of the Vilnius Ten in hastily casting their lot with the U.S. in the Iraq crisis made this task more difficult, and the ultimate achievement of European integration more distant.

Recently, the European Union has become a reference point when speaking of Europe. The "idea of Europe" is to be realized in a consolidated political (and, it is hoped, cultural) unit, which is currently under construction at the European Convention. Indeed, the European Union, which is becoming a federal superstate, can be viewed as precisely the primary manifestation of the project of making all of Europe a unified "old" Europe, albeit in a new form, so as to withstand pressures from nonEurope, i.e., the United States. The U.S., for its part, fails to appreciate the process, and rather - either willingly or involuntarily — obstructs it.

The oft-mentioned alliance between Europe and the U.S. appears to have been based almost exclusively on common military agendas, which for a time were complimented by economic advantages. As Duffield puts it, "the imperative of containing Soviet power and influence did much to force convergence among the foreign policies of the United States and its West European allies." One may even say that Europeans (the "old" ones, obviously) used the United States as a bulldog to scare off the other fierce dog, the USSR. However, once that threatening dog ceased to exist, the guard dog became less needed, if not altogether unnecessary. Though there were political

5 “Old America versus New Europe," The Economist, 22 February 2003, 32.

6 John S. Duffield, "Transatlantic Relations after the Cold War: Theory, Evidence, and the Future," International Studies Perspectives 2:2 (2001): 93. 
gestures made to reassure the continuity of the alliance (consider the Transatlantic Declaration of 1990, or the New Transatlantic Agenda of 1995), major European continental nations in the aftermath of the Cold War reconsidered their security and defense policies in favor of downgrading military expenditure, while the U.S., on the contrary, insisted on keeping military expenditures at a high level (the U.S. has been spending some 3.8 percent of its gross domestic product on defense). In the 1990s, then, the "old" Europe and the U.S. parted ways on the single issue that had kept them together for almost half a century. ${ }^{7}$

For the sake of fairness, it has to be pointed out that the "new" European states and the United States found each other; the Eastern Europeans, driven by an almost irrational fear of Russia, applied to the U.S. for military assistance, also hoping that American investments would follow. The U.S., for its part, recognized in Eastern Europeans potential long-term allies who will always be in need of protection that only the U.S. can provide. Thus was forged a pragmatic alliance of convenience, which will be sealed with the accession of virtually all the "new" European countries to membership in NATO.

The parting of ways between the U.S. and "old" Europe after the end of the Cold War fits well into the balance of power theory of international relations, which argues that "states will seek to balance the power of threatening states"; therefore, "whatever conflicts might have existed between them were overshadowed by the need to maintain a united front." ${ }^{8}$ Consequently, the demise of the threatening state(s) obscures the rationale behind the alliance, which becomes irrelevant to the new situation and the new balance of power among states. The possible solutions are either to discard the alliance or to radically readjust it to meet new conditions and new needs. Apparently, the second option was chosen. The mission and role of NATO are changing radically. The U.S., the leading and single capable member of the Alliance, has been reorienting NATO's focus from the "old" Europe to "new" Europe and, even more so, to areas altogether outside Europe. Leading European nations are seeking to replace U.S. involvement in Europe with indigenous European military forces. Meanwhile, NATO is being transformed from an organization of collective defense and security into an international coalition-which seems increasingly ad hoc, or, as was put by Bush Administration officials, to be a "coalition of the willing"-responsible for operations in regions that have virtually nothing to do with NATO. "Old" Europeans are reluctant to reinvent security threats so as to accept the de facto transformation of the organization, and only unwillingly submit to proposals put forward by the United States. The "new" Europeans, grateful for the American promise to protect them from possible enemies,

7 Javier Solana put essentially the same idea in more politically correct language, when he said that the "disappearance of an existential threat, the reduced strategic importance of the European theater, and the increasing U.S. focus on other priorities removed some of the glue from EU-U.S. relations." Javier Solana, "The Transatlantic Rift: U.S. Leadership after September 11," Harvard International Review (Winter 2003): 62.

8 Duffield, "Transatlantic Relations", 96. 
which are currently not specified as states but rather as clandestine terrorist organizations and the like, eagerly support and take part in American initiatives. If continued, the situation eventually might lead to a genuine rift inside Europe, and may have unwelcome effects on the future shape of the federal European state. NATO, then, could be blamed as a divider of Europe. One can only hope that the "new" Europeans will reassess their security policies and, after becoming full EU members, will come to see common European security and defense issues as their own.

From what has been said so far it would appear that there is not one rift but two: one between the "old" Europe and the United States, which, putting aside politically correct rhetoric, is quite real; and another rift between the "new" and "old" Europes, which is at this point more potential than real. What, then, are the causes of the rift between the "old" Europe and the U.S., and what are the prospects that this rift will engulf the whole of Europe, i.e., the future EU, or whatever structure evolves from it?

It has to be taken for granted that there are many political (and even personal) ambitions behind "old" Europe's antagonistic stance vis-à-vis the United States. There are also group interests involved, both political and economic. An additional factor that must be taken into account is the evident military impotence of most European countries, which has an impact on decision-making. Yet the opposing camps have found themselves divided over the issue of Iraq, a fact that is reflective of a much deeper cultural divide that separates the two.

This cultural divide essentially concerns how a society sees itself vis-à-vis other societies, and on what grounds it bases its relations with others. The Europeans ("old," of course), through their turbulent past, have come to recognize "Live and let live" as the fundamental maxim for dealing with societies that view the world differently. The U.S., on the other hand, has nurtured the approach of "Live like us." This fundamental difference in human relations has led to a profound difference in foreign policy (and other areas) between the Americans and Europeans. While Europeans are just as vocal champions of democracy and civil and human rights as the Americans, they do not see it as their duty to persuade others accept these values. Americans, on the contrary-or at least the current administration - feel it to be their mission to spread these values around the globe, by force if necessary. Put another way, Europeans tend to be introverts, while Americans are extroverts. ${ }^{9}$

These differences in weltanschauung presuppose different foreign policies. While there is no talk of a Pax Europeana, there is much to be said about the Pax Americana, which arguably has become the sole driving force behind the foreign policy of at least

9 Solana, a European par excellence, in his well articulated and balanced article "The Transatlantic Rift: US Leadership after September 11" looks at differences between Europe and the U.S. through the prism of the "fight against terrorism." Here he sees the same fundamental differences between the European and American approaches-Europeans and Americans have different perceptions of the threat that international terrorism might pose to the world. Consequently, Europeans, called by him a "civil power," prefer diplomacy, while Americans, a "military power," prefer military action in response to the terrorist challenge. Solana, "The Transatlantic Rift," 63. 
Republican governments in the U.S. in the post-Cold War era. As early as 1991, neoconservatives closely related to the Republican elite started speaking of the "unipolar moment," which they insisted had arrived. They argued that "the U.S. needed to use its overwhelming military and economic power to create a new Pax Americana." 10 In 1997, a group of unipolarists (among them Richard Cheney, Paul Wolfowitz, Norman Podhoretz, and Donald Rumsfeld) founded the Project for the New American Century, "which issued a statement of principles that called for an aggressive American policy of global domination."11 This fits well with the realization that Europeans are overwhelmingly secular, while U.S. is a markedly more religious nation. The missionary zeal of Americans can be explained in part by their religiousness. ${ }^{12}$ To the same effect, the religiously inflected political rhetoric of some top U.S. officials only further betrays the profound difference between these two world-views.

While Europeans, both leaders and commoners, abstain from labeling others in moral terms, the U.S. President and members of his administration have no scruples about calling other nations "evil," "rough," "outlaw," and similar things, while portraying themselves as "crusaders for freedom and liberty." Such rhetoric is perceived in the "old" Europe to be in bad taste at best and uncivilized at worst. Viewed from this perspective, U.S.-European relations can only diverge further, for it is hard to assume that the Europeans will subscribe to such a course of action in the foreseeable future. One more point needs to be made: the United States arrogated to itself the right of unilateral pre-emptive military action anywhere in the world. Though no nation (perhaps with the exception of China) can effectively measure up to the U.S. militarily, and all nations might feel potentially threatened, resentment is especially high in the "old" Europe, which considers unchecked brandishing of military power as barbarous, or at least leading to barbarity. ${ }^{13}$

The events and processes of the past two years revealed the unpleasant reality that Europeans and Americans have many more differences in their Weltanschauung than they have commonalities. This should not, however, lead us to rush to a Huntingtonian conclusion that Europe and the United States represent two different civilizations, which cannot help but be at odds with each other, once pragmatic alliances have fallen by the wayside. It is much more productive to see the U.S. and Europe as two different phases of the same civilization existing simultaneously. Thus, the differences between them, as real as they are, are in some respects a gift to humanity which ought to be cherished, for the true value of human society (also spoken of as the international

${ }^{10}$ Gary Dorrien, “Axis of One," Christian Century, 8 March 2003, 30.

${ }^{11}$ Dorrien, "Axis of One," 31.

${ }^{12}$ Solana also points to religiousness/secularism as an essential divide, which, as he says, "reflects [the] disparate nature of the two societies." Solana, "The Transatlantic Rift," 62.

${ }^{13}$ Consider Solana's words: "If the United States claims that power for itself, it will only foster resentment and hostility abroad and ultimately undermine its own interests." Solana, "The Transatlantic Rift," 64. 
community) lies in its diversity and multiculturalism, and not in its unanimity. Take, for example, the differences between European nations. Granted, they are substantial.

Yet Europe is on the road to a qualitatively new existence, where two-dozen nations with different cultural experiences and world-views opt to live in a joint superstate. Tolerance, respect, and wisdom within its borders and in its common foreign policy will be the features of the "new/old Europe." One can only hope for the U.S. to follow their lead and reconsider its priorities, both in the domains of cultural and foreign policy. 


\section{Bibliography}

Davison, H.D.. "Where is the Middle East." Foreign Affairs 39, no. 4 (1990).

Dorrien, Gary. "Axis of One." Christian Century (2003).

Duffield, John S.. "Transatlantic Relations after the Cold War: Theory, Evidence, and the Future." International Studies Perspectives 2, no. 2 (2001).

Huntington, Samuel. "Clash of Civilizations?" Foreign Affairs 72, no. 3 (1993).

Solana, Javier. "The Transatlantic Rift: U.S. Leadership after September 11." Harvard International Review (2003). 